P.I. Дзінько, О.I. Лісовиченко

\title{
ТРЕНУВАННЯ ШТУЧНИХ НЕЙРОННИХ МЕРЕЖ 3 ПОРОГОВОЮ ФУНКЦІЕЮ АКТИВАЦІЇ МЕТОДОМ ОБЕРНЕНОГО ПОШИРЕННЯ ПОХИБКИ
}

Анотація: Розглядається спосіб тренування нейронних мереж прямого поширення сигналу з оберненим поширенням похибки з використанням різних модифікацій порогової функції активації Хевісайда.

Ключові слова: штучна нейронна сітка, функція активації нейронів, функція Хевісайда.

\section{Вступ}

Метод оберненого поширення похибки [1] застосовуеться для тренування штучних нейронних мереж (ШНМ) прямого поширення сигналу (наприклад, багатошарових персептронів). Даний метод базуеться на мінімізації функції похибки шляхом отримання градієнту цієї функції і корекції вагових коефіціентів зв'язків вихідного та прихованих шарів нейронної мережі.

Даний метод, базуючись на градієнтах, застосовуеться тільки для мереж, функціії активації нейронів яких є диференційованими на всіх області визначення, яка застосовуеться для активації ШНМ [1]. Саме тому популярними функціями активації є:

- логістична функція (сигмоїда) (1)

- гіперболічний тангенс (2)

- гаусівська функція (3)

$$
\begin{gathered}
f(x)=\frac{1}{1+e^{-x}} \\
f(x)=\tanh (x) \\
f(x)=a e^{-\frac{(x-b)^{2}}{2 c^{2}}}
\end{gathered}
$$

Варто зазначити, що в цей же час одними з найпоширеніших функцій активації є порогова функція, чи функція Хевісайда (4) та лінійний підйом (5), які забезпечують більшу швидкість навчання, особливо в задачах класифікації.

$$
\begin{gathered}
f(x)=\{1, x \geqslant 0 ; 0, x<0\} \\
f(x)=\{-1, x<-1 ; 0,-1 \leqslant x<0 ; 1, x \geqslant 1\}
\end{gathered}
$$

(c) P.I. Дзінько, О.I. Лісовиченко, 2012 
Класичним варіантом застосування функції активації (1) е одношаровий персептрон (Розенблатта), який навчаеться згідно з дельтаправилом.

Проте описані функції не є диференційованими на своїй області визначення. Так, логістична функція (сигмоїда) недиференційовна при , функція гіперболічного тангенсу, при $x=-1$ та $x=1$.

\section{Постановка задачі}

Для прикладу, в якості вхідних даних для задачі візьмемо ШНМ прямого поширення сигналу з одним вхідним, одним вихідним та довільною кількістю прихованих шарів. В якості фрунції активації неронів прихованих шарів та нейронів вихідного шару оберемо фрункцію Хевісайда (4).

Дана задача, у випадку одношарової ШНМ вирішуеться за допомогою дельта-правила.

В частковому випадку задачі, коли активаційною функцією вихідного шару е порогова функція, а активаційними фрункціями внутрішніх шарів є диференційовні функції, можна скористатись комбінацією дельта-правила та методу градієнтного спуску для реалізації оберненого поширення похибки.

Проте така комбінація способів вирішення ускладнюе реалізацію, оскільки потребує створення додаткових підпрограм чи апаратних елементів (у випадку апаратної реалізації).

\section{Заміна активаційної функції}

В якості одного з методів вирішення поставленої задачі пропонуеться метод заміни вихідної порогової активаційної функції на подібну дирефенційовну.

Для цього необхідно модифікувати існуючі функції, які застосовуються в якості неперервних функцій активації при навчанні методом оберненого поширення похибки.

Поведінки функцій представлені на рис 1 . а, б. Як бачимо з рисунку, неперервні функції тангенс гіперболічний та сигмоїда ведуть себе подібно до порогової, за винятком того, що е гладкими та неперервними на всій області визначення.

Для того, щоб неперервні функції вели себе подібно до порогової функції, їх треба модифікувати:

- сигмоїду необхідно “притиснути” до осі ординат;

- тангенс гіперболічний можна підняти на 1 по осі ординат, двічі “притиснути" до осі абсцис і знову “притиснути" уже до осі ординат.

Для виконання цих операцій, внесемо відповідні модифікації в дані функції:

$$
f(x)=\frac{1}{1+e^{-x * a}}
$$




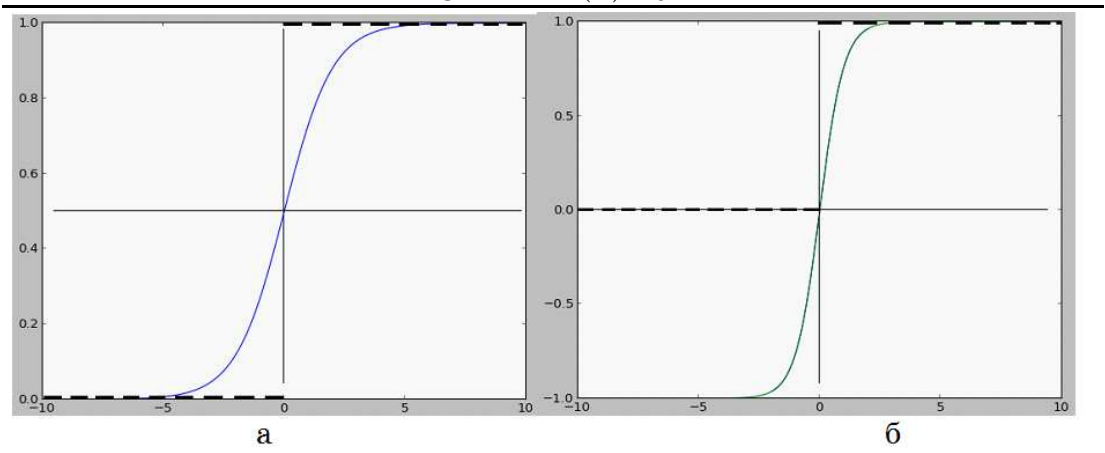

Рис. 1 - Диференційовні функції: (а) логістична та порогова функції; (б) логістична і тангенс гіперболічний

$$
f(x)=\frac{1+\tanh (a * x)}{2}
$$

Таким, чином, обидві функцій отримали деякий коефріціснт , зі збільшенням якого поведінка обраних неперервних функцій буде більш подібною до порогової функції, при чому не втрачаючи властивість диференційовності. Поведінка функцій з коефіцієнтом $a=20$ представлена на рис. 2. а, б.

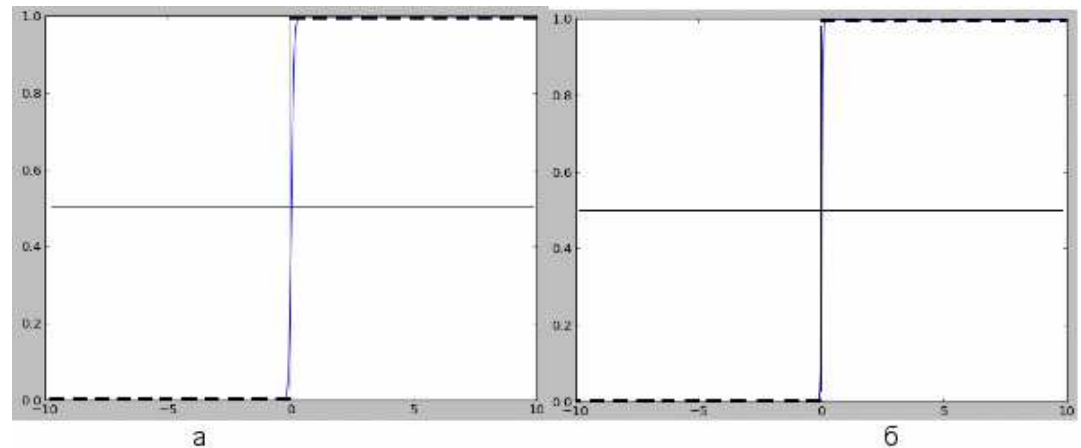

Рис. 2 - Модифіковані диференційовні фрункції та фрункція Хевісайда: (а) Логістична функція, a=20; (б) Тангенс гіперболічний, $\mathrm{a}=20$

\section{Експериментальне підтвердження важливості отриманих результатів}

В якості експерименту розв'яжемо класичну задачу побудови ШНМ прямого поширення сигналу для реалізації функції “виключаюче АБО” (“XOR”) з використанням модифікованих варіантів функцій активації. 
Як відомо, дана задача є задачею класифікації лінійно нероздільних елементів в двовимірному просторі, а тому має декілька шляхів вирішення:

1. При побудові одношарової ШНМ введененя нейрона зміщення [3] вводить додатковий вимір простору вхідних даних, що зсуває поріг активації вихідного нейрона. Даний метод не є універсальним, оскільки потребуе дослідження вхідних даних перед тим, як приступити до розв'язання.

2. Побудова двошарової ШНМ з застосуванням методів навчання, що враховують недиференційовні фрунції активації. Такий метод навчання не е універсальним, i, хоча, незручності від цього можуть бути зменшеними завдяки використанням шаблонів проектування програмного заюбезпечення [2], все ж потребуе введення в моделюючу систему додаткових підпрограм.

3. Побудова двошарової ШНМ з однією з вищеописаних функцій активації, поведінка якої наближається до порогової. Такий метод вирішення е універсальним, і повинен давати вищу швидкість навчання, ніж використання оригінальних функції активації (сигмоїдної чи гіперболічного тангенса).

Отже, проведемо навчання тришарової нейронної мережі, топологія якої зображена на рис. 3 , методом оберненого поширення похибки в двох варіантах:

1. В якості функції активації прихованого і вихідного шарів застосовуеться оригінальна сигмоїда.

2. В якості фрунції активації прихованого і вихідного шарів застосовуеться модифікована сигмоїда з параметром $a=100$.

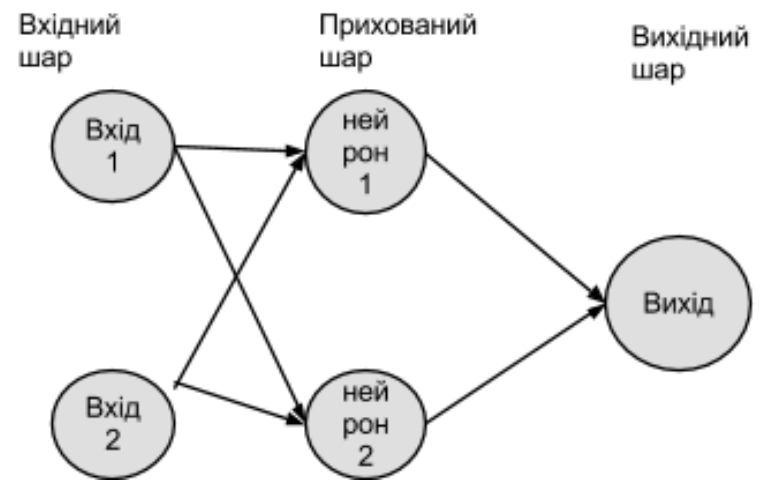

Рис. 3 - Тришарова повнозв'язна нейронна мережа 
Тренувальна вибірка

\begin{tabular}{|c|c|c|}
\hline Вхід 1 & Вхід 2 & Вихід \\
\hline 0 & 0 & 0 \\
\hline 0 & 1 & 1 \\
\hline 1 & 0 & 1 \\
\hline 1 & 1 & 0 \\
\hline
\end{tabular}

Тренування відбувається на наборі вхідних даних, представлених в табл. 1.

Проведемо тренування, умовою зупинки якого буде похибка не більше 0.001. Результати тренування приведені на гістограмі (рис. 4). Поставлений експеримент проведемо тричі з новими випадковим чином згенерованими ваговими коефіцієнтами зв'язків.

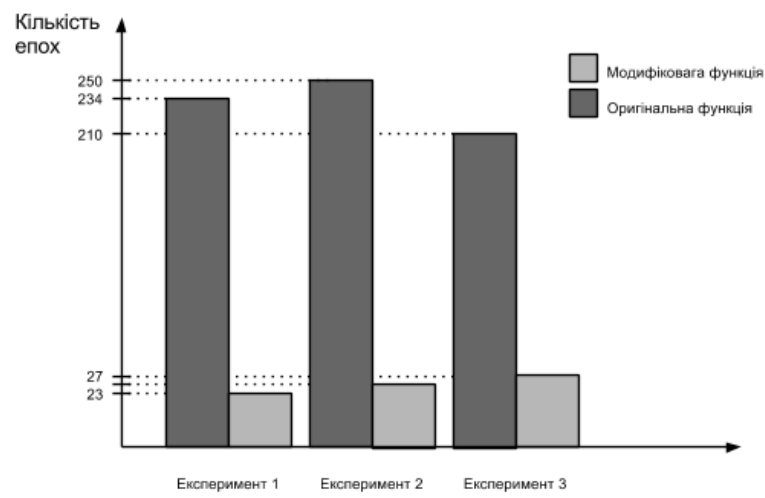

Рис. 4 - Результати проведення експерименту по тренуванню.

Як бачимо з отриманих результатів, модифікована фрункція має набагато кращі показники швидкості навчання, проходячи його в 9 разів швидше, ніж в класичному варіанті.

\section{Висновок}

Метод навчання ШНМ з оберненим поширенням похибки з використанням модифікованих диференційовних функцій активації для імітації поведінки порогової функції дозволяе вирішувати задачі, де порогова функція дає кращі показники швидкості навчання, ніж логістична чи гіперболічний тангенс.

На відміну від інших способів тренування ШНМ з недиференційовними функціями активації має наступні переваги: 
1. Даний підхід не потребує додаткових модифікацій в існуюче програмне забезпечення для моделювання ШНМ, що навчаються методом оберненого поширення похибки;

2. Навчання ШНМ швидше в 9 раз порівняно з оригінальними варіантами фрункцій активації в межах проведеного експерименту.

\section{Література}

1. Necht-Nielsen R. "Theory of the backpropagation neural network", International Joint Conference on Neural Networks, 1989.

2. Дзінько Р.I. Використання шаблонів проектування програмного забезпечення у моделюванні РТК / Дзінько Р.І., Гордійчук А.М., Лісовиченко О.I. - Адаптивні системи автоматичного управління, 19 (39) 2011.

3. Krogh A. Neural Network Ensembelles, Cross Validation and Active Learning / Krogh A., Vedelsby J. - Denmark 1995.

Отримано 15.11.2012 p. 